\title{
The Alkylation of DNA in vitro by Isopropyl Methanesulfonate
}

\author{
SOLVEI G W A L LES
}

Department of Radiobiology, Biochemistry Division, University of Stockholm, Box 6409, S-113 82 Stockholm, Sweden

\begin{abstract}
The consequences of alkylation of DNA in vitro with isopropyl methanesulfonate have been studied. In comparison deoxyguanosine, guanosine, and adenosine were also treated under the same conditions. Two derivatives were obtained from DNA. These were shown to have the same properties as one of the guanosine and one of the adenosine derivatives, respectively. Deoxyguanosine and guanosine gave the same derivatives. The main guanine derivative is probably 7-isopropylguanine.

The reaction rate constants for the different isopropylations were determined. The rate constants for alkylation of DNA bases were much higher than those of corresponding nucleosides.
\end{abstract}

The alkylating agent isopropyl methanesulfonate is a highly efficient muta1 gen. The frequency of the mutations induced by the mutagen in barley ${ }^{1}$ and $E$. coli ${ }^{2}$ has been shown to be proportional to the concentration of isopropyl methanesulfonate. Brookes and Lawley ${ }^{3,4}$ described the consequences of the alkylation of DNA by methyl (MMS) and ethyl methanesulfonate (EMS). 7-Alkylguanine and 3-alkyladenine were shown to be the main products. The reaction of the homologue isopropyl methanesulfonate (iPMS) with DNA, deoxyguanosine, guanosine, and adenosine were studied in this investigation. When DNA was alkylated by iPMS, two derivatives were obtained. One behaved like a guanine derivative and the other like an adenine derivative. The main guanine compound was identified by means of mass spectrometry.

The reaction rate constants for the different isopropylations of DNA, deoxyguanosine, guanosine, and adenosine were determined.

\section{MATERIALS AND METHODS}

Calf Thymus DNA (Type I) and deoxyguanosine were obtained from Sigma Chemical Co., guanosine and adenosine from Calbiochem and iPMS from Koch-Light Laboratories. 
In a preliminary experiment a DNA solution was treated three times $(8 \mathrm{~h}$ each at $25^{\circ} \mathrm{C}$ ) with $0.2 \mathrm{M}$ iPMS in a $1.5 \mathrm{M}$ phosphate buffer of pH 7.7, in order to get a high yield of alkylation. The reaction mixture was chromatographed directly after total consumption of iPMS on a column of Sephadex G-25, which was eluted by $0.05 \mathrm{M}$ phosphate buffer at $\mathrm{pH}$ 7.2. In the following experiments the nucleosides and DNA were alkylated by 0.1 or $0.2 \mathrm{M}$ iPMS in a $0.5 \mathrm{M}$ phosphate buffer at $\mathrm{pH}$ 7.7. The concentration of DNA was 1.25 $\mathrm{mg} / \mathrm{ml}$, that of guanosine and deoxyguanosine was $1 \mathrm{mg} / \mathrm{ml}$ and that of adenosine was $4 \mathrm{mg} / \mathrm{ml}$. The solutions were incubated for $8 \mathrm{~h}$ at $25^{\circ} \mathrm{C}$. After reaction $\mathrm{pH}$ had decreased to 6.8 . The reaction mixtures were chromatographed on a column of Sephadex G-10 $(1.5 \times 45 \mathrm{~cm})$, which was eluted by $0.05 \mathrm{M}$ phosphate buffer at $\mathrm{pH}$ 7.2. In order to get a comparable Sephadex chromatogram of the DNA derivatives, alkylated DNA was precipitated by 2 volumes of ethanol and the supernatant was chromatographed on the same column of Sephadex. The precipitated DNA was redissolved and hydrolysed in $1 \mathrm{M} \mathrm{HCl}$ at $100^{\circ} \mathrm{C}$ for $20 \mathrm{~min}$ and chromatographed on a column of Dowex $50\left(\mathrm{H}^{+}\right.$form, $0.7 \times 10 \mathrm{~cm}$ ) in order to determine the amount of guanine and adenine. Besides, all the derivatives obtained were chromatographed on the same column of Dowex 50. The Dowex column was developed by $2 \mathrm{M} \mathrm{HCl}$. Before application of the compounds to thin layer chromatography, they were hydrolyzed in $\mathrm{M} \mathrm{HCl}$ at $100^{\circ} \mathrm{C}$ for $20 \mathrm{~min}$ and then concentrated on a column of Dowex 50 . The fractions were evaporated to dryness in vacuum at $45^{\circ} \mathrm{C}$, redissolved and applied to thin layer chromatography. Thin layer chromatography of the samples from the different peaks was carried out on polygram cellulose powder (MN 300) sheets from Macherey, Nagel and Co. The developing system was butanol-formic acid-water $(77: 10: 13 \mathrm{v} / \mathrm{v})$. The nucleoside derivatives were checked for ribose by the orcinol test, which was carried out according to Bial, ${ }^{5}$ with the modification according to Mejbaum, ${ }^{6}$ and for deoxyribose by the diphenylamine test according to Dische. ${ }^{7}$ The absorption spectra of the different derivatives were recorded using a Zeiss RPQ 20A spectrophotometer.

A mass spectrum of guanosine I $_{\text {I }}$ was obtained with an LKB 9000 singlefocussing mass spectrometer using a direct insertion probe. The voltage of the electron beam was $70 \mathrm{eV}$.

\section{RESULTS}

Table 1 shows different chemical properties of the derivatives obtained. Only the derivatives from the nucleosides with spectra resembling those of the DNA derivatives were studied. Absorption spectra of all the different derivatives were recorded at different $\mathrm{pH}$ (Figs. 1-4). DNA and adenosine did not change its spectrum between $\mathrm{pH} 0-13$. DNA $\mathrm{II}_{\mathrm{I}}$ has a $\mathrm{p} K_{\mathrm{a}}$ between 5.2 and 6.1 and guanosine ${ }_{\mathrm{III}}$ has a $\mathrm{p} K_{\mathrm{a}}$ about 5.3.

The guanosine I $_{\text {I }}$ and adenosine $e_{1}$ were not separable from each other by thin layer chromatography in any of the systems tried. These were: 1) butanolformic acid-water $(77: 10: 13 \mathrm{v} / \mathrm{v}) ; 2)$ butanol-conc. $\mathrm{NH}_{3}$-water $(85: 2: 12 \mathrm{v} / \mathrm{v})$ : 3) methanol-conc. HCl-water $(7: 2: 1 \mathrm{v} / \mathrm{v}) ; 4)$ butanol-water $(86: 14 \mathrm{v} / \mathrm{v})$, and 5) formic acid-methanol-water $(85: 15: 5 \mathrm{v} / \mathrm{v})$. 
Table 1. Some properties of isopropylated derivatives from DNA, deoxyguanosine, guanosine, and adenosine.

\begin{tabular}{|c|c|c|c|c|}
\hline & $E_{(\mathrm{mm})} \mathrm{pH} 7$ & $\begin{array}{l}R_{F} \text { rel. to } \\
R_{F} \text { of } \\
\text { adenine }\end{array}$ & $\begin{array}{l}\text { Effluent volume } \\
\text { from a Dowex } \\
\text { column } \\
\text { (ml) }\end{array}$ & $\begin{array}{c}\text { Reaction rate } \\
\text { constants for } \\
\text { isopropylation } \\
k 1 \text { mole } \\
\text { at } 25^{-1} \mathrm{C}\end{array}$ \\
\hline $\mathrm{DNA}_{\mathbf{I}}$ & 258 & 2.2 & 32 & $0.52^{b}$ \\
\hline $\mathrm{DNA}_{11}$ & 256 & 1.3 & 8 & $0.15^{b}$ \\
\hline Deoxyguanosine $_{\mathbf{I}}$ & 258 & 2.3 & 32 & 0.095 \\
\hline Deoxyguanosine $_{\text {III }}$ & 256 & 1.4 & 21 & 0.0084 \\
\hline Guanosin $_{I}$ & 258 & 2.1 & 32 & 0.13 \\
\hline Guanosine $_{\text {III }}$ & 256 & 1.5 & 20 & 0.056 \\
\hline Adenosine $_{\mathrm{I}}$ & 258 & 2.2 & 43 & 0.12 \\
\hline Adenosine & 256 & 1.3 & 8 & 0.024 \\
\hline
\end{tabular}

a System: BuOH:HCOOH:H, $\mathrm{O}$ (77:13:10 v/v).

$b$ The yield calculated in per cent of total amount of free base.

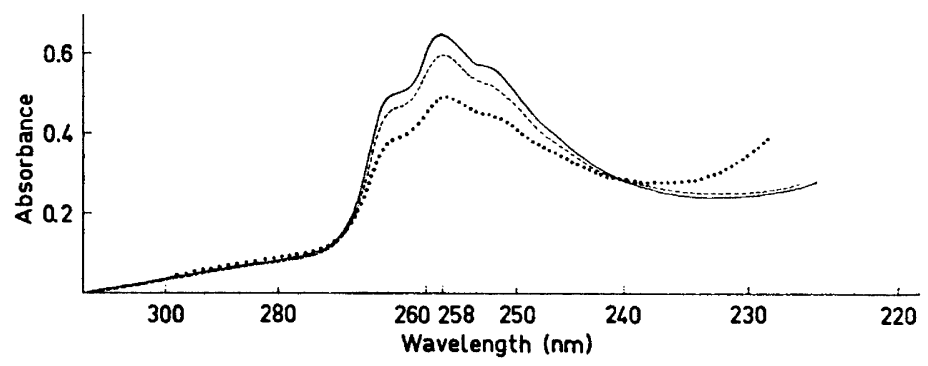

Fig. 1. Absorption spectra of $\mathrm{DNA}_{\mathrm{I}}$ at $\mathrm{pH} 2$ (continuous line), 7 (dashed line), and 12 (dotted line).

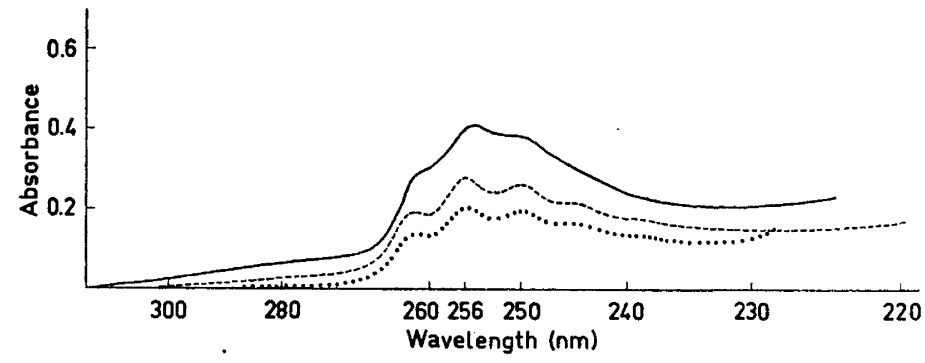

Fig. 2. Absorption spectra of $\mathrm{DNA}_{\mathrm{II}}$ at $\mathrm{pH} \mathrm{2,} \mathrm{7,} \mathrm{and} 12$ (curves marked as in Fig. 1).

The reaction rate constants were calculated according to the formula ${ }^{8}$

$$
k=\frac{k_{\mathrm{H}, \mathrm{O}}\left[\mathrm{H}_{2} \mathrm{O}\right][\mathrm{DNA}-\mathrm{PA}]}{[\mathrm{DNA}-\mathrm{P}][\mathrm{AA}]_{0}}
$$

Acta Chem. Scand. 24 (1970) No. 6 


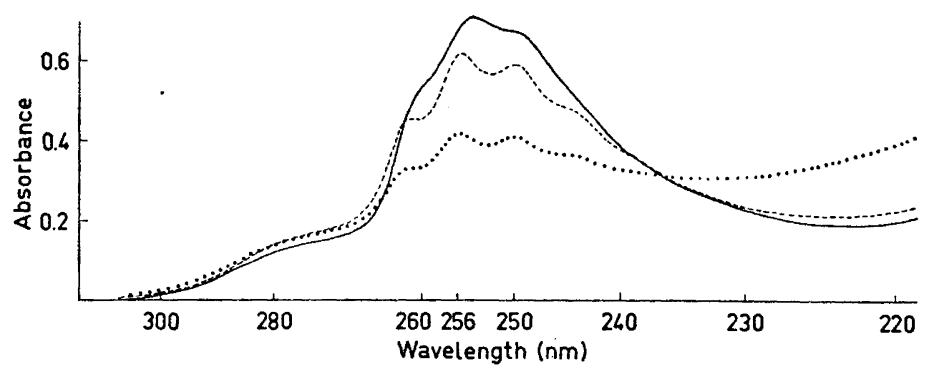

Fig. 3. Absorption spectra of guanosine $\mathrm{II}_{\mathrm{I}}$ at $\mathrm{pH} \mathrm{2,} \mathrm{7,} \mathrm{and} 12$ (curves marked as in Fig. 1).

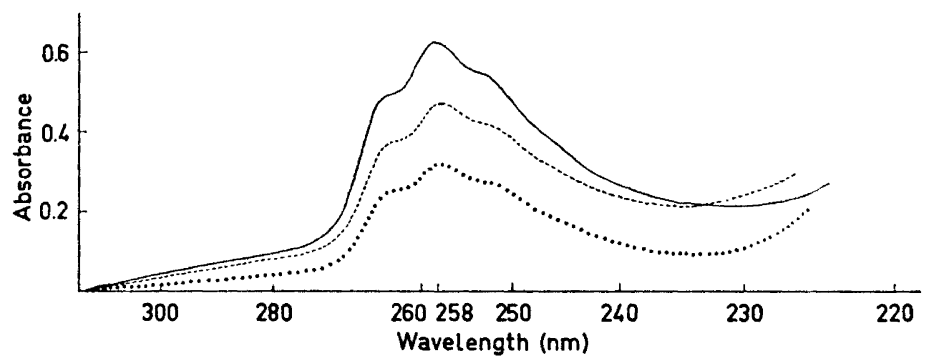

Fig. 4. Absorption spectra of adenosine $\mathrm{I}_{\mathrm{I}}$ at $\mathrm{pH} \mathrm{2,} \mathrm{7,} \mathrm{and} 12$ (curves marked as in Fig. 1).

The yields of the isopropyl bases are calculated in per cent of the total amount of free bases and they were considered to have the same extinction coefficient as guanine and adenine, respectively.

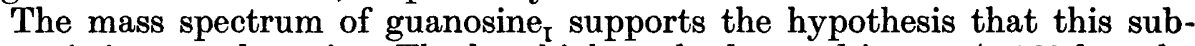
stance is isopropylguanine. The last high peak observed is at $m / e ~ 163$ but the molecular weight of isopropylguanine is 193. However, both methyl groups are easily split off during the operation and the residue of the molecule should then have $\mathrm{M}=163$.

The characteristic peaks of 7-methylguanine at $m / e 124,96,53,43$ and $28^{9}$ are also found in the spectra of isopropylguanine. Besides, dominating peaks are found at 122,119 and 79 .

No sugar was found in the orcinol and diphenylamine test of the derivatives. This means that the time of hydrolysis of the free base is short compared to the time of synthesis of the nucleoside.

Figs. 5-8 show the results of gel filtration of the reaction mixtures, except in the case of DNA where the supernatant was filtrated. Peak II in Figs. 6 and 7 shows an absorption spectrum, which is similar to those of guanosine and deoxyguanosine, $E_{\max } 278,252$ and $E_{\min } 267$ and 236 at pH 7.2.

\section{DISCUSSION}

The reaction rate constants for isopropylation of DNA are higher than those for the corresponding reactions of the nucleosides. Price et al. ${ }^{10}$ observed the same fact at alkylation of nucleic acid components with nitrogen mustard Acta Chem. Scand. 24 (1970) No. 6 


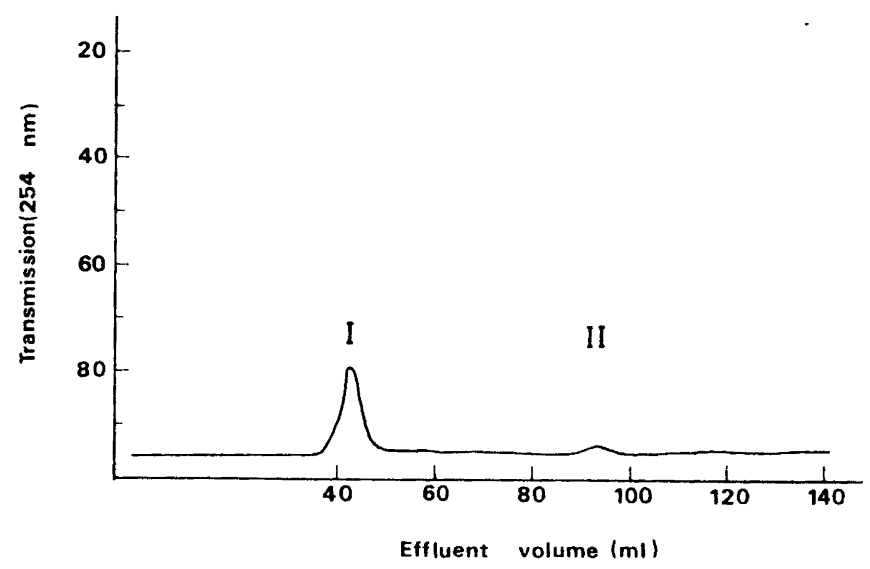

Fig. 5. Gel filtration of the supernatant from precipitated isopropylated DNA. Peak I: DNA $_{\text {I }}$ and peak II: DNA II .

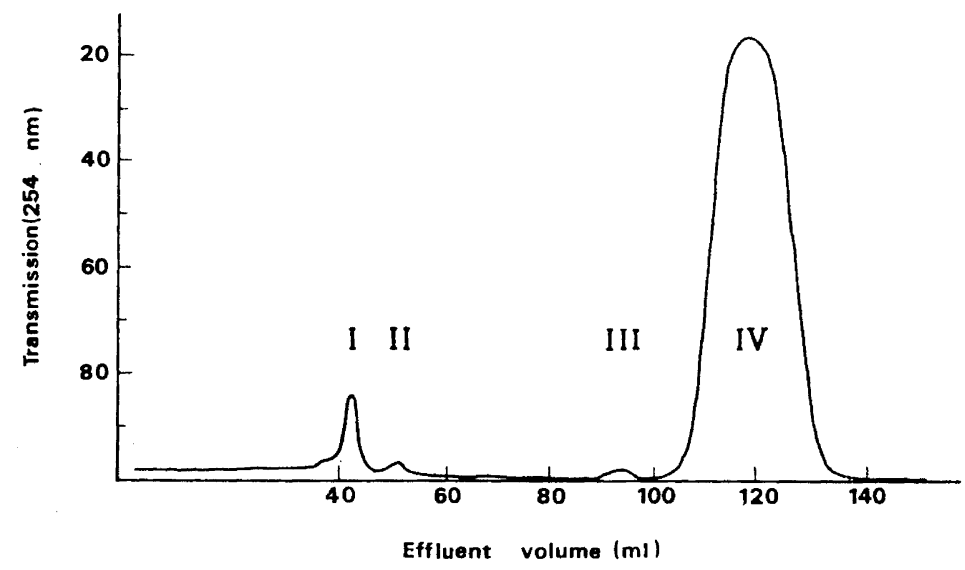

Fig. 6. Gel filtration of isopropylated deoxyguanosine. Peak I: deoxyguanosine $\mathrm{I}_{\mathrm{I}}$, peak III: deoxyguanosine ${ }_{\text {III }}$ and peak IV: deoxyguanosine. (Peak II see Text.)

(HN2). They gave two explanations for this, 1) enhancement of nucleophilicity by electron transfer in stacked bases; 2) alkyl transfer from phosphate triesters. The first explanation was supposed to be most likely. Measurement of the competition factors showed that the reactivity of phosphates in the nucleotides and polyadenylic acid are approximately $10 \%$ of that of DNA guanine. In comparison, the reaction rate constants for the isopropylation of DNA guanine are 5 times higher than that of DNA phosphate ( $c f$. below). The reaction rate constants for methylation (by methyl methanesulfonate) of guanosine and of guanine residue in DNA were found to be 0.4 and 0.5 1 mole $^{-1} \mathrm{~h}^{-1}$, respectively. According to Osterman-Golkar et al. ${ }^{11}$ this should 


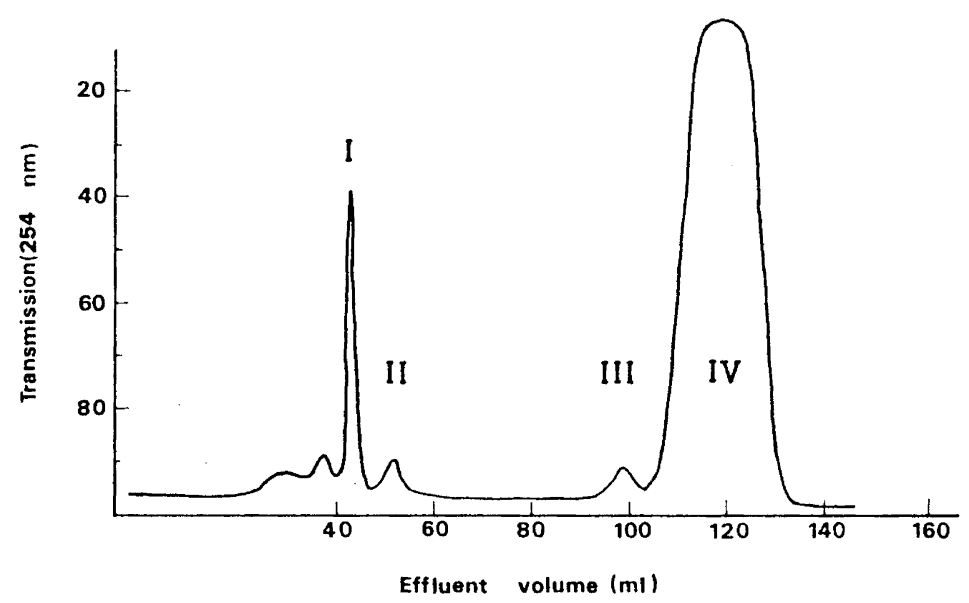

Fig. \%. Gel filtration of isopropylated guanosine. Peak I: guanosine $e_{\text {I }}$, peak III: guanosine ${ }_{\text {III }}$ and peak IV: guanosine. (Peak II see Text.)

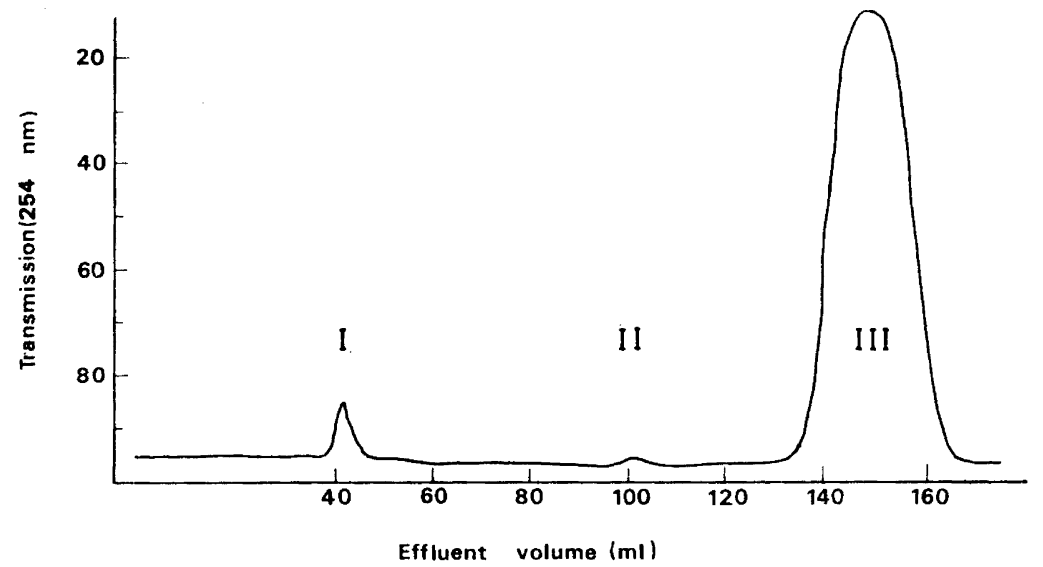

Fig. 8. Gel filtration of isopropylated adenosine. Peak I: adenosine , peak II: adenosine $_{\text {II }}$ and peak III: adenosine.

correspond to a value $n=3.8$ of the nucleophilicity of $\mathrm{N}-7$ of guanosine. If the substrate constant, ${ }^{12} s$, for iPMS at $25^{\circ} \mathrm{C}$ is 0.30 , a theoretical value of $k=0.181 \mathrm{~mole}^{-1} \mathrm{~h}^{-1}$ is calculated. This is in acceptable agreement with the experimentally found value, $0.131 \mathrm{~mole}^{-1} \mathrm{~h}^{-1}$. While the reaction rate constants for methylation of guanosine and DNA are almost the same, iPMS gives a four times more rapid alkylation of DNA than of guanosine. A correspondingly higher mutagenic effectiveness was found in experiments with $E$. coli. ${ }^{2}$ It is quite possible that a positively charged molecule, such as the dimethylcarbonium ion, which is the reactive intermediate in the $S_{N} l$ reaction of iPMS, will

Acta Chem. Scand. 24 (1970) No. 6 
react faster with the negatively charged DNA molecule than with guanosine. A similar influence of charge might be involved in the reaction of $\mathrm{HN} 2$ with DNA. ${ }^{10}$

Walles and Ehrenberg ${ }^{8}$ gave a value for the rate constant for reaction between DNA-P and iPMS of 0.09 at $25^{\circ} \mathrm{C}$. In this case DNA was treated with tritium labelled iPMS and then precipitated and the radioactivity of the DNA was recorded. Anyway, it has now been shown, that the isopropylated bases were found in the supernatant, when DNA was precipitated immediately after the consumption of iPMS. It may therefore be assumed that in the first case only the phosphate alkylation was registered.

The most likely site of alkylation of guanine is the $\mathrm{N}-7$ position, because it has the highest nucleophilicity.10 From the data of mass spectrum it also seems likely that 7-isopropylguanine is the main derivative obtained at isopropylation of DNA, deoxyguanosine, and guanosine. The most nucleophilic group in adenine is $\mathrm{N}-1,{ }^{10}$ but in DNA this is involved in hydrogen bonds; therefore the most likely derivative from DNA is 3-isopropyladenine. This is in agreement with the fact that the main derivative obtained from adenosine is not the same adenine derivative as is obtained from DNA, which corresponds to the minor derivative from adenosine.

The alkylation of position 7 in guanine causes a positive charge, which is distributed between $\mathrm{N}-7$ and $\mathrm{N}-9 .{ }^{13}$ This weakens the bonds at these positions so that hydrolysis takes place and the base will either lose the alkyl group or be separated from its sugar residue. The half-lives for the hydrolysis of methyland ethyl deoxyguanosine at $37^{\circ} \mathrm{C}$ are about 3 and $6 \mathrm{~h}$, respectively, according to Lawley and Brookes.4 No sugars were found from the isopropyl products after $2 \mathrm{~h}$ incubation at $37^{\circ} \mathrm{C}$. These derivatives are hydrolysed at least at the same rate as they are synthesized.

Acknowledgements. Professor Lars Ehrenberg is thanked for valuable discussions during the course of this work. This investigation was supported by Grant No. 138-35 from the Swedish Natural Science Research Council.

\section{REFERENCES}

1. Ehrenberg, L., Lundqvist, U., Osterman, S. and Sparrman, B. Hereditas 56 (1966) 277.

2. Turtóczky, I. and Ehrenberg, L. Mutation Res. 8 (1969) 229.

3. Brookes, P. and Lawley, P. D. Biochem. J. 80 (1961) 496.

4. Lawley, P. D. and Brookes, P. Biochem. J. 89 (1963) 127.

5. Bial, M. Deut. Med. Wochschr. 28 (1902) 253, 477.

6. Mejbaum, W. Z. physiol. Chem. 258 (1939) 117.

7. Dische, Z. Mikrochemie 8 (1930) 4; Mikrochim. Acta 2 (1927) 13.

8. Walles, S. and Ehrenberg, L. Acta Chem. Scand. 23 (1969) 1080.

9. Rice, J. M. and Dudek, G. O. J. Am. Chem. Soc. 89 (1967) 2719.

10. Price, C. C., Gaucher, G. M., Koneru, P., Shibakawa, R. and Sowa, R. J. Biochim. Biophys. Acta 166 (1968) 327.

11. Osterman-Golkar, S., Ehrenberg, L. and Wachtmeister, C. A. Radiation Botany 10 (1970) 303.

12. Swain, C. G. and Scott, C. B. J. Am. Chem. Soc. 75 (1953) 141.

13. Bautz, E. and Freese, E. Proc. Natl. Acad. Sci. U.S. 46 (1960) 1585.

Received December 22, 1969.

Acta Chem. Scand. 24 (1970) No. 6 